\title{
Testicular Torsion and Contralateral Torsion of the Appendix Testis
}

\section{Testis Torsiyonu ve Kontralateral Apendiks Testis Torsiyonu}

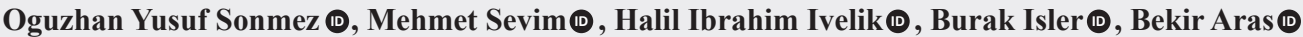

Department of Urology, Kutahya Health Science University Faculty of Medicine, Kutahya, Turkey

Cite as: Sonmez OY, Sevim M, Ivelik HI, Isler B, Aras B.

Testicular torsion and contralateral torsion of the appendix testis. Grand J Urol 2021;1(2):75-7.

Corresponding Author: Halil Ibrahim Ivelik / Department of Urology, Kutahya Health Science University Faculty of Medicine, Kutahya, Turkey / halib_ive@hotmail.com ORCID ID: 0000-0001-5298-0045

\begin{abstract}
Testicular torsion is a urological emergency that results in deterioration of the blood supply of the testicle and ischemia as a result of the rotation of the spermatic cord around itself. It may show a wide clinical variety with inflammatory manifestations varying from mild abdominal pain to severe scrotal pain. Orchiectomy may be required in cases which are delayed and cannot be operated urgently. Torsion of the testis and epididymis are other frequently seen causes of acute scrotum in children. Growth of masses and hormonal stimulation in the adolescent age cause an increase in the tendency of the torsion of appendix testis which have a small pedicle and epididymis. In the presence of sudden scrotal pain, testicular torsion should be considered, if there is clinical suspicion, patients should be evaluated with color doppler ultrasound (CDUS) and scrotal exploration should be performed immediately. A 20-year-old male whose clinical picture, and scrotal ultrasonography suggested the presence of testicular torsion is presented in this case report.
\end{abstract}

Keywords: acute scrotum, testicular torsion, torsion of the appendix testis

Öz

Testis torsiyonu; spermatik kordun kendi etrafında dönmesi sonucu testisin kanlanmasının bozulması ve iskemi ile sonuçlanan bir ürolojik acildir. Hafif karın ağrısından, şiddetli skrotal ağrıya kadar enflamatuar bulguların olduğu geniş bir klinik çeşitlilik gösterebilir. Gecikmiş ve acil tedavi edilemeyen vakalarda orşiektomi gerekebilir. Apendiks testis torsiyonu ve epididim torsiyonu çocuklarda sık görülen bir diğer akut skrotum nedenidir. Adelösan çağda kitlelerinin büyümesi ve hormonal stimülasyon, küçük bir pediküle sahip appendiks testis ve epididimisin torsiyone olma eğiliminin artmasına sebep olur. Ani gelişen skrotal ağrı varlı̆̆ında testis torsiyonu akla gelmeli, klinik şüphe duyulursa Doppler ultrason ile değerlendirilmeli ve skrotal ekplorasyon vakit kaybetmeden yapılmalıdır. Bu vaka sunumunda kliniği ve skrotal ultrasonografisi testis torsiyonu düşündüren 20 yaşındaki olgu sunulmaktadır.

Anahtar kelimeler: akut skrotum, testis torsiyonu, apendiks testis torsiyonu 


\section{Introduction}

Testicular torsion (TT) is one of the urological surgical emergencies. Failure to receive adequate treatment in time may result in the loss of the testicle. TT is divided into extravaginal and intravaginal torsions. Extravaginal torsion is frequently seen in prenatal period and newborn infants [1,2]. It may present with a firm and a non-transilluminating bluish scrotal mass. color doppler ultrasonography (CDUS) usually does not show signs of vascular torsion. Detorsion cannot be applied manually. It is generally not possible to achieve detorsion surgically which usually requires orchiectomy. Although orchiopexy can be performed on the contralateral testicle during orchiectomy the evidence-based logic of this practice is controversial. Intravaginal torsion; is most common between the ages of 1218 years. Its sudden onset clinic is usually accompanied by moderate or severe scrotal pain which must be treated urgently. In suspicious cases, clinical examination is performed with or without anesthetic block and scrotal palpation should be tried to see whether the lower pole of the epididymis is separated from the lower pole of the testicle. In doubtful cases, testicular blood flow should be evaluated by CDUS. Scrotal exploration should not be delayed in the presence of clinical uncertainty.

Torsion of the appendix testis and appendix epididymis occurs in adolescents due to their small pedicles as they turn around more easily. It is generally observed in the patient group above the age of 16 . The clinical picture is in the form of a palpable painful mass in or on the testicle. In the torsion of appendix testis, a blue dot sign can be observed on the scrotum skin [3]. Scrotal exploration should be performed, if the torsion of the spermatic cord is suspected.

\section{Case Presentation}

Our case was a 20-year-old male patient who referred to our clinic with pain in both testicles (more severe in the right testicle) for three days. In the examinations that were performed on the patient, no abnormalities were found in the complete urinalysis, biochemistry parameters, and hemogram. In the physical examination of the patient who was diagnosed as acute scrotum both testicles were painful. Additionally the pain increased with elevation of the testis. Scrotal color doppler ultrasonography was performed, which revealed that the contours of both testicles were normal, the parenchyma was homogeneous, and torsion was detected in the distal part of the left spermatic cord. The blood supply of the left testicle was decreased compared to the right.

After pre-diagnosis of left testicular torsion, scrotal exploration was performed. Torsion of the left spermatic cord was detected, so detorsion was performed (Figure 1). During follow-up, improvement in the left testicular blood flow was observed with colour change on superficial testicular tissue and testis was fixed to a left scrotal dartos pouch which was prepared priorly during the procedure. Right scrotal exploration performed priorly because of patient had significant right scrotal pain. On the other hand ischemic and thrombosed right appendix testicle was observed (Figure 2). The appendix of the testis was excised from its ischemic pedicle, and right testicle was fixed to the scrotum.

\section{Discussion}

Torsion of the spermatic cord is a rare disease commonly seen in adolescent males. Its incidence is $1 / 4000$ in the male population under 25 years old. Although sudden scrotal pain is usually seen in the torsion of the spermatic cord, some children may experience less pain with slow onset [4]. The differential diagnosis includes traumatic epididymitis, acute hydrocele, inguinal hernia, testicular tumours, and Henoch-Schönlein purpura. One of the helpful tools in the differential diagnosis is "Prehn's sign". The Prehn's sign is the change in the intensity of pain with the elevation of the testicle. During the elevation of the testicle, the pain increases in torsion, while it is relieved in epididymitis and orchitis. In these cases, scrotal exploration should be performed as soon as possible in case of evidence of torsion in the clinical history and physical examination.

Definitive diagnosis of testicular torsion is made with color doppler ultrasound, while blood flow is visualized on the normal side but is absent on the affected side. In less than 360 degrees of torsion, scrotal color doppler ultrasonographic examination may show a small amount of blood flow in the symptomatic testicle which can be a misleading false- negative result. In orchitis, parenchymal echoes decrease heterogeneously; in the rare presence of parenchymal hemorrhage, an increase in echogenicity may be observed [5].

Torsion of the appendix testis is the most common cause of scrotal pain in children [6]. Spontaneous recovery may be achieved non-operatively. Scrotal color doppler ultrasonography is an imaging method that can be used in clinically suspected cases. If there is a suspicion of torsion or an increase in

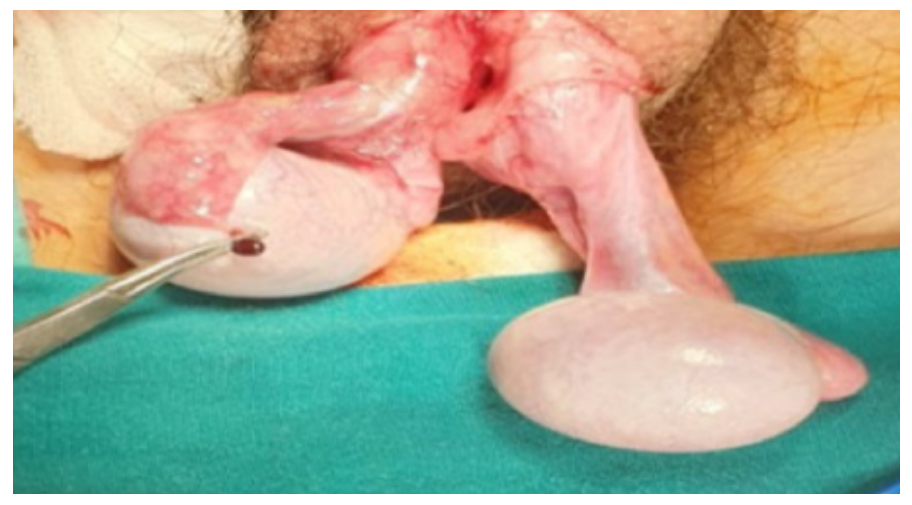

Figure 1. The left testicle and detorsioned right appendix testis and visually improved blood flow

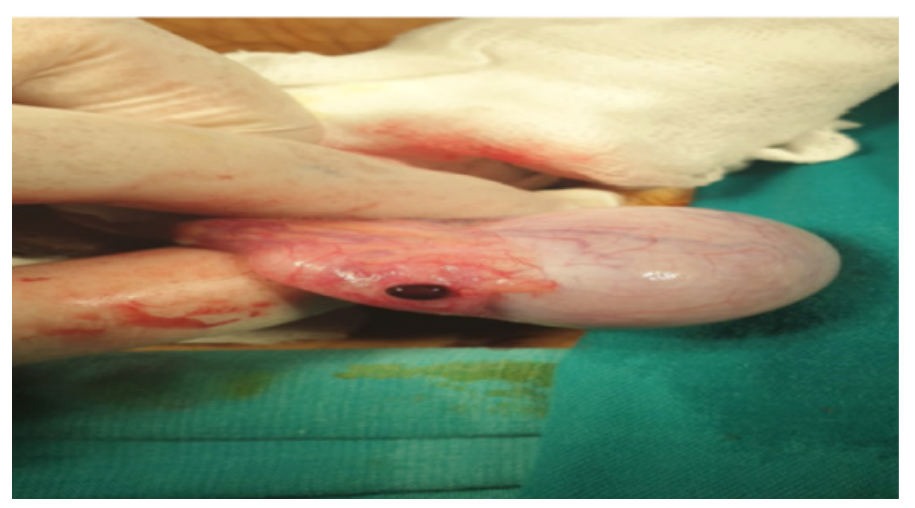

Figure 2. Torsion of the right appendix testis 
inflammatory findings, immediate exploration should be performed and the torsioned appendix testis should be excised away from its ischemic pedicle [7].

In our case, after the patient presented with acute scrotal pain and the absence of left testicular blood flow detected in doppler ultrasonography, emergency scrotal exploration was performed. Torsion of the left testis and the right testicular appendix are rare causes of the acute scrotum, which were contralaterally observed in our case. It should be kept in mind that the torsion of the appendix testis is more common in the pediatric age, however it may be present in adolescents and rarely it is accompanied with testicular torsion as was in our case.

Ethics Committee Approval: N / A

Informed Consent: An informed consent was obtained from the patient.

Publication: The results of the study were not published in full or in part in form of abstracts.

Peer-review: Externally peer-reviewed.

Authorship Contributions: Any contribution was not made by any individual not listed as an author. Concept - O.Y.S., M.S.; Design - O.Y.S., M.S.; Supervision - B.A.; Resources M.S., H.I.I., B.I.; Materials - M.S., H.I.I., B.I.; Data Collection and/or Processing - O.Y.S., M.S., H.I.I., B.I.; Analysis and/or Interpretation - O.Y.S., M.S., H.I.I., B.I.; Literature Search M.S., H.I.I., B.I.; Writing - O.Y.S., M.S., H.I.I.; Critical Review - O.Y.S., B.A.

Conflict of Interest: The authors declare that they have no conflict of interest.

Financial Disclosure: The authors have declared that they did not receive any financial support for the realization of this study.

\section{References}

[1] Das S, Singer A. Controversies of perinatal torsion of the spermatic cord: A review, survey and recommendations. J Urol 1990;143:231-3. https://doi.org/10.1016/S0022-5347(17)39919-6.

[2] Ryken TC, Turner JW, Haynes T. Bilateral testicular torsion in a pre-term neonate. J Urol 1990;143:102-3. https://doi.org/10.1016/S0022-5347(17)39879-8.

[3] Dresner ML. Torsed appendage Diagnosis and management: Blue dot sign. Urology 1973;1:63-6. https://doi.org/10.1016/0090-4295(73)90116-7.

[4] Anderson PAM, Giacomantonio JM. The acutely painful scrotum in children: Review of 113 consecutive cases. Can Med Assoc J 1985;132:1153-5. https://doi.org/10.1016/s0022-5347(17)47615-4.

[5] Baud C, Veyrac C, Couture A, Ferran JL. Spiral twist of the spermatic cord: A reliable sign of testicular torsion. Pediatr Radiol 1998;28:950-4. https://doi.org/10.1007/s002470050507.

[6] Flanigan RC, Dekernion JB, Persky L. Acute scrotal pain and swelling in children: a surgical emergency. Urology 1981;17:51-3. https://doi.org/10.1016/0090-4295(81)90012-1.

[7] Rajler J. Congenital anomalies of the testis and scrotum. In: Walsh P, Retik A, Vaughan E, Wein A, editors. Campbell's Urol. 8th ed., Philadelphia, PA: W.B. Saunders; 2002, p. 2379-91. 